\title{
PERFORMANCE ANALYSIS OF OPTICAL SPHERICAL WAVE IN BIOLOGICAL TISSUE
}

Serap ALTAY ARPALI', Department of Electronic and Communication Engineering, Çankaya University, Turkey, saltay@cankaya.edu.tr

(iD https://orcid.org/0000-0002-8803-0567)

Received: 02.06.2021, Accepted: 27.10.2021

*Corresponding author

Research Article

DOI: $10.22531 /$ muglajsci.947190

\begin{abstract}
In this study, bit error rate (BER) of optical spherical wave is investigated to analyze the performance of spherical wave through in soft tissue. Within this scope, average BERs $(<B E R>)$ of optical spherical wave are extensively examined depends on the different tissue and turbulence parameters that are random changes in the refractive index of the soft tissue, the tissue length from source to receiver, and the outer scale of the tissue turbulence. It is observed from the outputs that the $<B E R>$ increases with increasing value of outer scales, tissue lengths and random changes in the refractive index of the soft tissue. Also we investigated $\angle B E R>$ values of the optical spherical wave for the different values of the one half of the quantified slope in the range of power-law scaling. It is found that smaller $<B E R>s$ of the spherical wave are obtained for decreasing values of one half of the quantified slope in the range of power-law scaling.

Keywords: Optical spherical wave propagation, Bit error rate, Biological tissues, Tissue turbulence
\end{abstract}

\section{YUMUŞAK DOKU İÇERISIINDE YAYILAN KÜRESEL DALGANIN PERFORMANS ANALİZi}

\section{Özet}

Bu çalışmada, yumuşak doku içerisinde yayılan küresel dalganın performansını analiz edebilmek için, optiksel küresel dalganın bit-hata-olasılığını (BER) inceledik. Bu kapsamda, optiksel küresel dalganın ortalama BER'i (<BER>), yumuşak dokunun kırınım indeksindeki rastgele değişimleri, kaynak ve detektör arasındaki doku uzunluğu, büyük ölçekli doku türbülansı gibi değişik doku ve türbülans parametrelerine bağlı olarak ayrıntılı olarak çalışılmıştır. Çalışmanın sonucunda doku türbülansının büyük ölçek değeri, doku uzunluğu ve yumuşak dokunun kırınım indeksindeki rastgele değişimleri arttıkça <BER> değeri artmıştır. Ayrıca optiksel küresel dalganın <BER> değerleri üstel ölçek kuralının sınırları içinde belirlenen eğimin yarı değerinin farklı büyüklükleri için incelenmiştir. Üstel ölçek kuralının sınırları içinde belirlenen eğimin yarı değerinin farklı büyüklüklerinin azalan değerleri için küresel dalganın <BER>'nin düştüğü gözlemlenmiştir.

Anahtar Kelimeler: Optiksel küresel dalya yayılımı, Bit-hata-olasılı̆̆ı, Biyolojik doku, Doku türbülansı

Cite

Arpali, S, A., (2021). "Performance Analysis of Optical Spherical Wave in Biological Tissue”, Mugla Journal of Science and Technology, 7(2), 36-39.

\section{Introduction}

Bio-optical imaging technologies depend on the interaction of light with tissues and for those imaging modalities the main degradation mechanisms on the image quality are absorbance and scattering [1-3]. Absorbance is mostly caused by laser wavelength and the absorbance ratio of the micro organs that consist of tissue. Scattering is generated by the collision of photons with molecular structure of the tissue and results attenuation of light intensity at the detector plane. Thus, both of these factors affect the BER values of the images that directly determine the quality of the treatment in medicine [1]. Another important criterion is tissue turbulence that occurs due to spatial and temporal variations of refractive index of the organelles [4]. Turbulence results intensity variation at the detector plane and increase signal to noise ratio (SNR) values related with scintillation [5-7]. To overcome the tissue turbulence issues, different methods have been proposed such as beam shaping or phase matching at the receiver [8]. For the characterization of light in biological tissue, various beam types are studied depends on the propagation properties in tissue turbulence [9-12]. From these results, it is seen that refractive index fluctuations distort the laser beam intensity due to tissue turbulent so performance of medical imaging systems is strongly affected. In our previous work, we analyzed the effects of the intensity 
fluctuations of spherical wave in soft biological tissue based on the medium and propagation characteristics [13]. Furthermore, our group [14] has analyzed the effect of Gaussian beam through in tissue in terms of bit error rates and intensity fluctuations. Recently, signal to noise ratio is derived to investigate effects of the Laguerre-Gaussian beam on the biological tissue [15]. In the current paper, we derived BER of optical spherical wave that propagates weakly turbulent biological tissue. The average BER of optical spherical wave variations against the average SNRs are plotted and analyzed for tissue and turbulence parameters. These outcomes can be used in optical medical imaging modalities for evaluations of transmission link in terms of some performance parameters such as BER.

\section{Formulation}

Average bit error rate $\angle B E R>$ is given below based on the on-off keying modulation in direct detection systems [16],

$$
<B E R>=\frac{1}{2} \int_{0}^{\infty} P_{I}(u) \operatorname{erf} c\left[\frac{\langle S N R\rangle u}{2 \sqrt{2}}\right] d u
$$

here, mean signal to noise ratio $\langle S N R\rangle$ is formulated below,

$$
<S N R>=\frac{S N R_{0}}{\sqrt{\left(\frac{P_{S O}}{\left\langle P_{S}\right\rangle}\right)+m^{2} S N R_{0}^{2}}}
$$

Here, signal to noise ratio without the tissue turbulence is given as $S N R_{0}$ [16]. Signal power in biological tissue without the turbulence is $P_{S O}$ and averaged power at detector of the signal that propagates in soft tissue is $\left\langle P_{S}\right\rangle$. Normalized signal with unit mean is $u=s /\left\langle i_{s}\right\rangle$, complementary error function is $\operatorname{erfc}(\mathrm{x}), P_{I}(u)$ is the probability density function depends on the log-normal distribution in soft tissue expressed as,

$$
P_{I}(u)=\frac{1}{u m \sqrt{2 \pi}} \exp \left\{-\frac{\left[\ln (u)+\frac{1}{2} m^{2}\right]^{2}}{2 m^{2}}\right\}
$$

where $m^{2}$ is the intensity fluctuations of optical spherical wave that propagates in soft tissue turbulence which is expressed in [13]

$$
\begin{aligned}
& m^{2}=8 \pi^{2} R e\left\{\int _ { 0 } ^ { L } d \eta \int _ { 0 } ^ { \infty } \kappa d \kappa \left[T^{2}(\eta, \kappa)+\right.\right. \\
& \left.\left.|T(\eta, \kappa)|^{2}\right] \Phi_{n}(\kappa)\right\}
\end{aligned}
$$

Here $L$ is the tissue length from source to receiver, $R e$ represents the real part, $\eta$ denotes the distance along the transmission axis, |.| is the absolute value, $\kappa$ is the magnitude of the two dimensional spatial frequency, and

$$
T(\eta, \kappa)=i k \exp \left[-0.5(k L)^{-1}(L-\eta)(i \eta) \kappa^{2}\right],
$$

where $k=2 \pi / \lambda$ and $\lambda$ is the wavelength, $i=(-1)^{0.5}$ and $\Phi_{n}(\kappa)$ based on the spectrum that is the turbulence in a soft tissue whose refractive index variations in a random manner is derived by [4]

$$
\Phi_{n}(\kappa)=\frac{4 \pi\left\langle\delta n^{2}\right\rangle(\alpha-1) L_{0}^{2}}{\left(1+\kappa^{2} L_{0}^{2}\right)^{\alpha}}
$$

where, $\delta n^{2}$ is the random changes in the refractive index and it is order of the 0.001-0.005 in most soft tissues, $\alpha$ is the one half of the quantified slope in the range of power-law scaling and $\alpha$ changes from 1.28 to $1.41,\langle$.$\rangle shows the ensemble average, the outer scale of$ the tissue turbulence is $L_{0}$ that based on the soft tissue characteristics and generally takes values of quite a few micro meters.

\section{Results}

In this section to analyze the effect of optical spherical wave that propagates in soft tissue, $\angle B E R>$ values against $\langle S N R>$ are exhibited by evaluating Equation (1) numerically. Penetration depth of electromagnetic waves in tissue is the main factor that effects the beam propagation in terms of system performance thus for all the figures, $\lambda$ is selected as $1064 \mathrm{~nm}$ for providing the maximum penetration distance in the soft tissue [17]. Laser beam, medium and propagation parameters that are used in the analyses are given in the inset of the Figures.

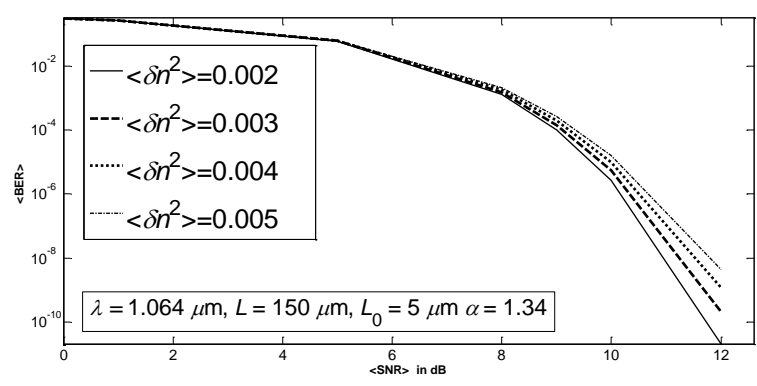

Figure 1. $\angle B E R>$ of spherical wave against $<S N R>$ for various size of $n^{2}$.

In Figs. 1-3, fixed $\alpha$ is selected as 1.34 that is the one half of the quantified slope. For all figures it is seen that with increasing $<S N R>$ values, $<B E R>$ tends to exponentially decay. In Fig. 1, we demonstrated $<B E R>$ variation versus $<S N R>$ at various size of $\delta n^{2}$. It is shown from the Fig. 1 that larger $\delta n^{2}$ yields increased $<B E R>$ values. As it is seen with decreasing $\delta n^{2}$, sketch approaches to the lower $<B E R>$ values so it provides better performance in terms of reducing the effect of scintillation at detector plane. Thus we can conclude that the smaller values of random variations in the refractive index provide a better contribution to increase link feasibility. 


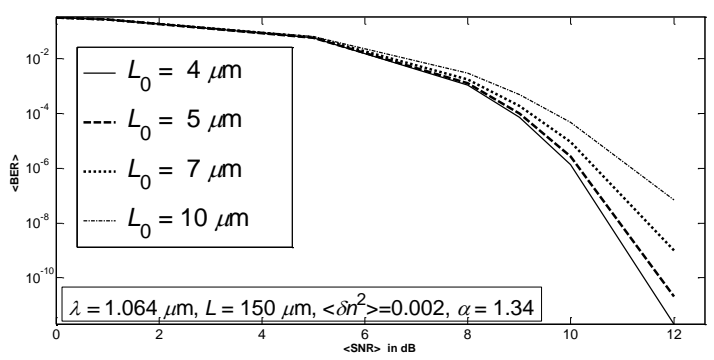

Figure 2. $<B E R>$ of spherical wave against $<S N R>$ for various size of $L_{0}$.

In Fig. 2, we investigated $\langle B E R>$ values variation versus $<S N R>$ depends on the various size of outer scale of tissue turbulence $L_{0}$. We observed from the Fig. 2 that $\angle B E R>\mathrm{s}$ of optical spherical wave decrease for smaller $L_{0}$. From Fig. 2 we can conclude that for a feasible high performance imaging system, $L_{0}$ should be selected as small as possible to provide lower $\langle B E R>$. Reducing the size of the outer scale of tissue turbulence means laser beam experiences relatively lower sized perturbation of the wave front interaction with turbulence eddies at micro scales. So in this sense the $S N R$ boost is reasonable.

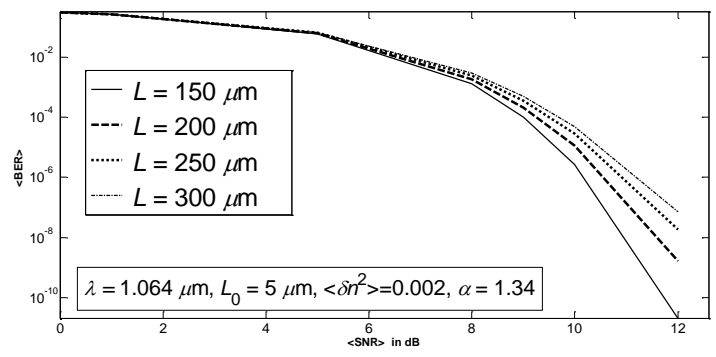

Figure 3. $<B E R>$ of spherical wave against $<S N R>$ for various size of $L$.

We observed $\langle B E R>$ values variation versus $\langle S N R>$ at different tissue length $L$ in Fig. 3. According to the Fig. 3, $\angle B E R>$ values decrease with smaller tissue length $L$. Since for the smaller tissue lengths spherical wave experiences lower attenuation of refractive index variations during the propagation, system performance improves with decreasing $\angle B E R>$ values. $\angle B E R>$ variation with respect to the $\angle S N R>$ depends on the different one half of the quantified slope $\alpha$ is demonstrated on Fig. 4.

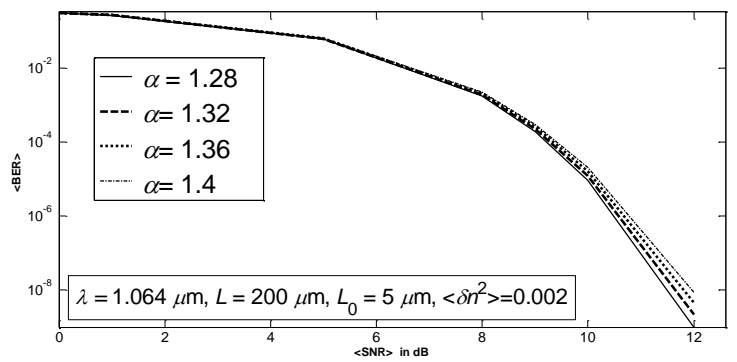

Figure 4. $<B E R>$ of spherical wave against $<S N R>$ for various size of $\alpha$.
Fig. 4 shows that when $\alpha$ increases, $\angle B E R>$ increases at each $\langle S N R>$. As it is seen, decreasing $\alpha$ creates better performance in terms of enhancement of $\angle B E R>$ values. In the spectrum formula since $\alpha$ has an inversely proportional effect on the scintillation it is reasonable to observe lower $\angle B E R>$ values at higher powers. So we can inference that for providing a better link performance of a tissue like communication medium it is better selecting $\alpha$ as large as possible.

\section{Conclusion}

In weak tissue turbulence, $\angle B E R>$ of optical spherical wave in soft biological tissue are deeply studied. Depend on the tissue parameters $\angle B E R>$ values versus $\langle S N R>$ are derived. We observed from the figures that the effects of tissue and turbulence characteristics when spherical wave transmits the weakly turbulent tissue. These are the random changes in the refractive index of the soft tissue, the tissue length from source to receiver, the one half of the quantified slope and outer measure of the soft tissue turbulence. From the graphical outputs, we demonstrated that decreasing the one half of the quantified slope creates better performance in terms of $<B E R>$ of optical spherical wave in soft tissue. For the smaller tissue lengths, system performance improves with decreasing $\angle B E R>$ values. Also depends on the outputs, we can improve the system performance depends on the $\angle B E R>$ with smallest values of random changes of the refractive index of the tissue in weakly turbulent medium and outer scale of tissue turbulence.

\section{Acknowledgment}

Thanks to Çankaya University and TÜBİTAK under Grant No 213E035 that funds this study.

\section{References}

[1] Niemz, M. H., Laser-Tissue Interactions Fundamentals and Applications, Springer, Germany, 2007.

[2] Tuchin, V. V., Tissue Optics: Light Scattering Methods and Instruments for Medical Diagnosis, SPIE, Washington, 2007.

[3] Wang, L. V.; Zimnyakov, D. A., Optical Polarization in Biomedical Applications, Springer, New York, 2006.

[4] Schmitt, J. and Kumar, G., "Turbulent nature of refractiveindex variations in biological tissue", Opt. Lett., Vol. 21 No.16, 1310-1312, 1996.

[5] Sun, J., Lee, S. J., Wu, L., Santinoranont, M., Xie, H., "Refractive index measurement of acute rat brain tissue slices using optical coherence tomography", Opt. Express, Vol.20 No.2, 1084-1095, 2012.

[6] Carvalho, S., Gueiral, N., Nogueira, E., Henrique, R., Oliveira, L., Tuchin, V. V. J., "Wavelength dependence of the refractive index of human colorectal tissues: comparison between healthy mucosa and cancer", Biomedical Photonics \& Eng., Vol.2 No.4, 040307-1-040307-9, 2016.

[7] Wang, Z., Tangella, K., Balla, A., Popescu,G. J., "Tissue refractive index as marker of disease", Biomed. Opt., Vol.16 No.11, 116017-1-116017-7, 2011.

[8] Fisher, A. D. and Warde, C., "Technique for real-time highresolution adaptive phase compensation", Opt. Lett., Vol.8 No.7, 353-355, 1983. 
[9] Liu, X. and Zhao, D., "The statistical properties of anisotropic electromagnetic beams passing through the biological tissues", Opt. Commun., Vol.285 No.21-22, 4152 4156, 2012.

[10] Luo, M., Chen, Q., Hua, L., Zhao, D., "Propagation of stochastic electromagnetic vortex beams through the turbulent biological tissues", Phys. Lett. A., Vol.378 No.3, 308-314, 2014.

[11] Lu, X.; Zhu, X.; Wang, K.; Zhao, C.; Cai, Y., "Effect of biological tissueson the propagation properties of anomalous hollow beams", Optik, Vol.127 No.17, 1842-1847, 2016.

[12] Gökçe, M. C. and Baykal, Y., "Effects of liver tissue turbulence on propagation of annular beam", Optik, Vol.171, 313-318, 2018.

[13] Baykal, Y., Arpali, Ç., A. Arpali, S., "Scintillation index of optical spherical wave propagating through biological tissue", Journal of Modern Optics, Vol.64 No.2, 138-142, 2017.

[14] A. Arpali,S., Arpali, Ç., Baykal, Y., "Bit error rate of a Gaussian beam propagating through biological tissue", Journal of Modern Optics, Vol.67 No.4, 340-345, 2020.

[15] Li, Y., Zhang, Y., Zhu, Y., Yu, L., "Modified biological spectrum and SNR of Laguerre-Gaussian pulsed beams with orbital angular momentum in turbulent tissue", Opt. Express, Vol.27 No.7, 9749-9762, 2019.

[16] Andrews, L. C., Phillips, R. L., Hopen, C. Y., Laser Beam Scintillation with Applications, SPIE, Washington, 2001.

[17] Smith, A. M., Mancini, M. C., Nie, S., "Bioimaging: second window for in vivo imaging", Nature Nanotechnology, Vol.4 No.11, 710-711, 2009. 